\title{
Autochthonous Plasmodium vivax malaria in a Greek schoolgirl of the Attica region
}

\author{
Chariclia V Loupa ${ }^{1 *}$, Konstantina Tzanetou ${ }^{2}$, Ioannis Kotsantis ${ }^{1}$, Stylianos Panopoulos ${ }^{1}$ and Moyssis Lelekis ${ }^{1}$
}

\begin{abstract}
In August 2009, one case of autochthonous malaria due to Plasmodium vivax was diagnosed in Greece in a young woman residing in the Eastern Attica region. The source of infection could not be identified. No other autochthonous malaria cases have been described in the Attica region since 1974. This was a sporadic case with no evidence of further local transmission, and no more cases have been reported in Attica up to now, two years later.
\end{abstract}

Keywords: Malaria, Autochthonous, Plasmodium vivax, Greece

\section{Background}

In non-endemic countries, malaria cases are mostly imported (from travelers or immigrants), but blood transfusion malaria, or malaria in transplant recipients, or even cases of "airport malaria" can occasionally be seen [1]. Greece has been malaria free since 1974. However, rare cases of autochthonous malaria are occasionally reported. Recently, in August 2011, an announcement was posted by European Centres for Disease Prevention and Control (ECDC) and American Centers for Disease Control and Prevention (CDC) that six autochthonous malaria cases were reported in southern Greece [2,3]. An autochthonous case in a schoolgirl in the Attica region in 2009 is hereby described.

\section{Case presentation}

A 17-year-old young woman of Greek origin, living in the Eastern Attica region, was admitted to hospital (midAugust, 2009), because of high fever (up to $40.3^{\circ} \mathrm{C}$ ) of abrupt onset with chills for eight days. She also reported sore throat, headache, remarkable weakness and sweating with unpleasant smell. Fever was almost periodic, being higher every second day. Anti-pyretic drugs were causing lysis with excess sweating. Her past medical history was unremarkable. She denied travelling abroad and had no history of blood transfusion. Upon admission, patient was

\footnotetext{
* Correspondence: ch-loupa@hol.gr

'2nd Department of Internal Medicine, "A. Fleming" General Hospital, 14

25th March St., Melissia, Athens GR-15127, Greece

Full list of author information is available at the end of the article
}

in good condition, and physical examination revealed mild hepatosplenomegaly. There were multiple skin lesions suggesting insect bites, especially on lower limbs. During the first 48 hours of hospitalization, she had fever up to $40^{\circ} \mathrm{C}$, symptomatically treated with paracetamol. Initial blood evaluation showed normocytic, normochromous anaemia (haematocrit $31.3 \%, \mathrm{MCV}=89.6 \mathrm{fL}, \mathrm{MCHC}=32.3$ ), thrombocytopaenia (platelets $48,000 / \mu \mathrm{L}$ ), with a normal leukocyte count. Liver function tests yielded slightly abnormal results: AST $28 \mathrm{u} / \mathrm{L}$, ALT $71 \mathrm{u} / \mathrm{L}$ (reference range < 40), LDH $943 \mathrm{u} / \mathrm{L}$ (reference range 230-450), and total bilirubin $1.2 \mathrm{mg} / \mathrm{dL}$ (reference range $<1,0$ ). Kidney function tests and coagulation study were normal. ESR was $58 \mathrm{~mm}$, and CRP $139 \mathrm{mg} / \mathrm{L}$ (reference range < 5). Chest $\mathrm{x}$-ray and urinalysis were normal. Two sets of blood cultures and urine culture were negative. Viral (cytomegalovirus, Epstein-Barr virus), bacterial (brucella) and parasitic (Toxoplasma, Leishmania) serology was negative, and throat swab PCR for H1N1 antigens was also negative. Based on serology (Ra-test, ANA, anti-DNA), there was no evidence of systemic disease. Ultrasonography of the upper abdomen showed enlarged liver and spleen (17.2 and $14.1 \mathrm{~cm}$, respectively). The initial Giemsa-stained peripheral blood smear was negative for Plasmodium. In a second peripheral blood smear, obtained on the third hospital day, Plasmodium parasites were identified. The patient was started on mefloquine. When the smear was re-examined by an experienced microbiologist, the parasite was identified as Plasmodium vivax according to morphological characteristics of trophozoites, immature/
C Biomed Central

() 2012 Loupa et al; BioMed Central Ltd. This is an Open Access article distributed under the terms of the Creative Commons Attribution License (http://creativecommons.org/licenses/by/2.0), which permits unrestricted use, distribution, and reproduction in any medium, provided the original work is properly cited. 
mature schizonts, and gametocytes (Figure 1A-D). Parasitaemia was approximately $3 \%$. After completing mefloquine therapy (750 mg po $\times 1$, then $500 \mathrm{mg}$ po $\times 112 \mathrm{~h}$ later), the patient's condition improved and after assessment of G-6-PD levels, she was discharged on primaquine (30 mg base po $\times 1$ ) for 14 days. Seen as an outpatient, she remains in good health and relapse-free to September 2011 (two years after discharge).

The young woman is of Greek origin and living in Nea Makri. This small summer holiday town of 14,809 permanent residents is located in Eastern Attica region, $32 \mathrm{~km}$ from the city of Athens and $12 \mathrm{~km}$ from "El. Venizelos" International Airport [4]. Many immigrants from endemic countries live in this area, and they work at plant nurseries located approximately $10 \mathrm{~km}$ from the small town. There are also still water pools and even swamps at a $10 \mathrm{~km}$ distance. The patient had no travel history in malaria endemic countries. She did not mention any visits to the airport, and she had no history of blood transfusion. She had a schoolmate from Africa, who was apparently healthy. A limited enquiry that was conducted did not reveal other people with malaria-like symproms in the patient's family or school.

\section{Discussion and conclusion}

In Greece, malaria is among the mandatory reported diseases. According to official data, 20-30 new cases of malaria are reported every year [5]. Like all non-

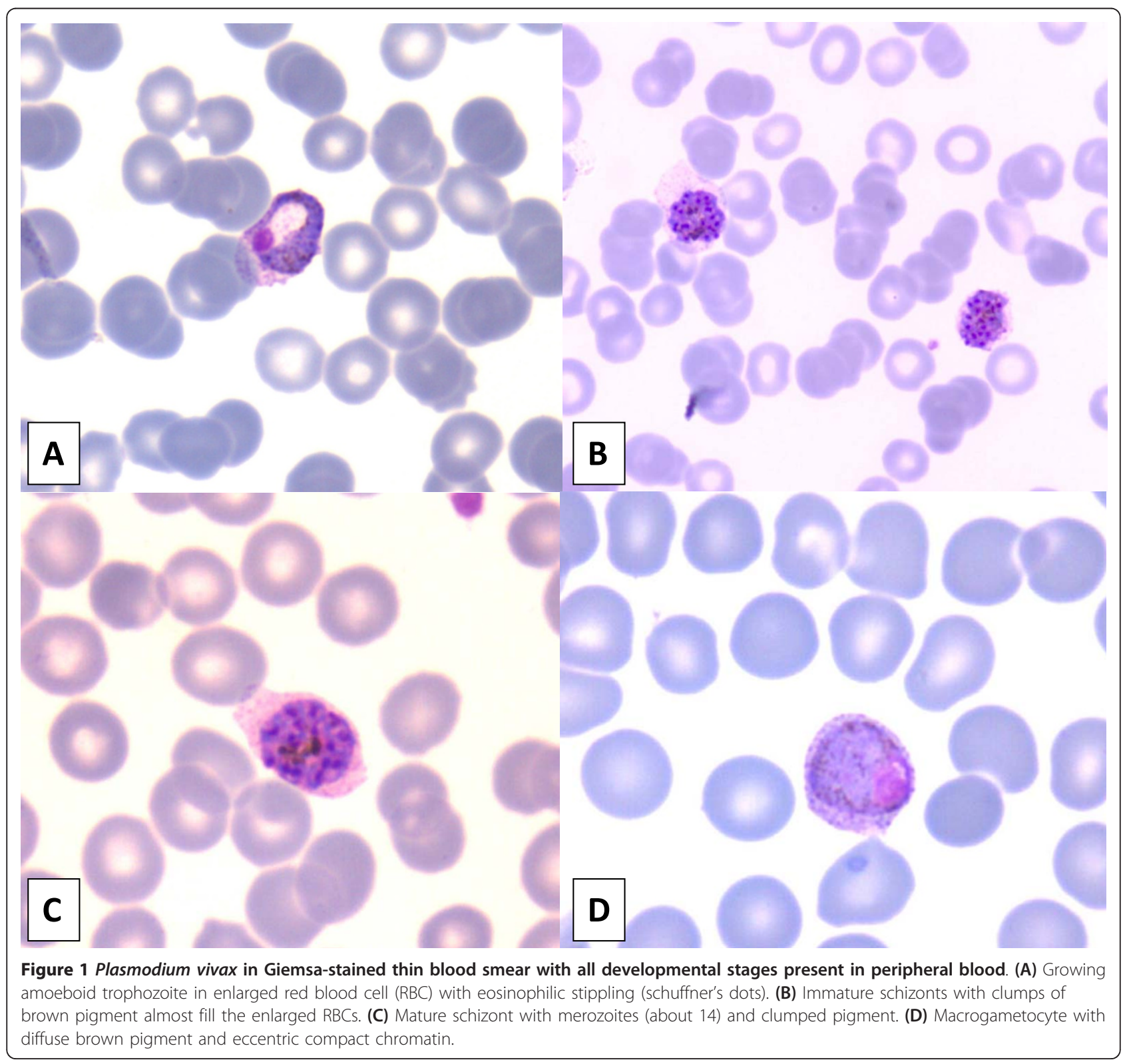


endemic countries, cases are mostly imported (from travelers or immigrants), but there are also few reports of blood transfusion malaria [1]. However, a few autochthonous cases of malaria were reported in Thrace (Northern Greek region) [6-8], in the mid- and late Nineties. Since then, there were no more autochthonous cases until 2009, when six cases of autochthonous malaria were reported (through the European Surveillance System - TESSy) and one again in 2010, all residing in the same area of Evrotas, a small agricultural and wetland area (Lakonia, Peloponnese, southern Greece) $[9,10]$. These cases were all caused by $P$. vivax [2]. Since June 2011, another six cases of autochthonous malaria were reported $[2,3]$. All six cases were diagnosed with $P$. vivax malaria. Four of these were again from Evrotas region. One case is a young Roma child, and three cases are adult Greek citizens not belonging to a minority group. The two remaining cases are in adult Greek citizens that reside close to the town of Chalkida, in the district of Evoia, where no previous autochthonous malaria cases had been reported. Both the Lakonia and Evoia districts have a large population of non-documented illegal migrant farm workers from malaria-endemic countries. In August 2011, a P. vivax malaria infection was diagnosed in a Romanian citizen who had been working in agriculture in Evrotas region [11].

The described autochthonous malaria case was diagnosed in August 2009. It was reported to KEELPNO (the Greek Centers for Disease Control and Prevention) through the mandatory notification system. This is the only case of autochthonous malaria in Attica (Athens city and suburbs region) before 2011. It was caused by P.vivax, as all the Laconia and Evoia cases, and, as previously noted, in this particular Attica area a lot of immigrants reside and work. This was a sporadic case with no evidence of further local transmission.

The most likely explanation of the few reported autochthonous cases is limited transmission of the disease to nearby residents or workers by local mosquitoes (vectors), infected from undiagnosed imported malaria cases or asymptomatic gametocyte carriers infected outside Greece. This is attributed to the large number of documented and non-documented (illegal) immigrants from endemic countries of Asia and Africa. Also, climate change, causing high temperatures during summer time, is favourable for mosquito growth [10].

Isolated autochthonous cases caused by $P$. vivax, Plasmodium falciparum and Plasmodium ovale have been reported in other European countries, such as in Spain, France, Italy and Germany. In Spain, a case of malaria was reported from the Aragon region in 2010 [12], and there was also one in 2001 that may have been airport malaria [13]. One case was diagnosed in Corsica, France, and two in Marseille, in spring and summer 2006
$[14,15]$. In Italy, there were two cases in 1997-1998, with one of them linked to an imported case from India $[5,16]$ and one in late Eighties [17]. In Germany, there were two cases in a paediatric ward in 1997 [18]. Such cases never resulted in established local transmission involving more than a few cases.

During 2010 and 2011, attention was paid to mosquito-borne infections in Greece because of West Nile virus outbreaks and KEELPNO has responded by enhancing its surveillance system and intensifying mosquito control. Efforts to destroy mosquitoes using insecticides are currently undertaken by the Greek government [19].

Although malaria risk in Greece remains extremely low, and the country has implemented control measures, individual measures to prevent mosquito bites, such as using insect repellent when outdoors during the peakbiting period for mosquitoes (dusk and dawn), seem reasonable. Also, health practitioners must include malaria in the differential diagnosis, and try to rapidly identify and report suspected malaria cases to respective authorities. Diagnosis is based on microscopy (blood smears) and/or serology. When there is a high suspicion index for malaria, repeated peripheral blood smears should be examined, drawn every six to 12 hours for a minimum of three days, preferably upon fever or chills [20].

\section{Author details}

2nd Department of Internal Medicine, "A. Fleming" General Hospital, 14 25th March St., Melissia, Athens GR-15127, Greece. ²Department of Microbiology, "Alexandra" General Hospital, 80 V. Sofias Ave. \& 2-4 Lourou St., Athens GR-11528, Greece.

\section{Authors' contributions}

$\mathrm{CL}$ and $\mathrm{ML}$ were attending the patient. $\mathrm{KT}$ was the microbiologist that identified the parasite species. IK and SP carried out the epidemiological study. All authors read and approved the final manuscript.

\section{Competing interests}

The authors declare that they have no competing interests.

Received: 25 September 2011 Accepted: 21 February 2012 Published: 21 February 2012

\section{References}

1. Loupa C, Tzanetou K, Stefanoudaki A, Kallioras E, Malamou-Lada E, Lelekis M: Plasmodium malariae infection complicated with hemophagocytic syndrome after recent blood transfusion. latriki 2007, 91:243-249.

2. European Centre for Disease Prevention and Control (ECDC): Rapid Risk assessment: Autochthonous Plasmodium vivax malaria in Greece.[http:// ecdc.europa.eu/en/publications/Publications/

110823_TER_Risk_Assessment_Malaria_Greece.pdf].

3. Centers for Disease Control and Prevention (CDC): Malaria cases: Greece [http://wwwnc.cdc.gov/travel/news-announcements/malaria-greece.htm]

4. Municipality of Marathon. [http://site.marathon.gr/nea-makri.html].

5. World Health Organization (WHO): Regional Office for Europe. Centralized information system for infectious diseases (CISID) database: Malaria [http:// data.euro.who.int/cisid]

6. Kampen H, Maltezos E, Pagonaki M, Hunfeld KP, Maier WA, Seitz HM: Individual cases of autochthonous malaria in Evros Province, northern Greece: serological aspects. Parasitol Res 2002, 88:261-266. 
7. Kampen H, Proft J, Etti S, Maltezos E, Pagonaki M, Maier WA, Seitz HM: Individual cases of autochthonous malaria in Evros Province, northern Greece: entomological aspects. Parasitol Res 2003, 89:252-258.

8. Sabatinelli G, Ejov M, Joergensen P: Malaria in the WHO European Region (1971-1999). Euro Surveill 2001, 6:pii = 213[http://www.eurosurveillance.org/ ViewArticle.aspx?Articleld=213].

9. Andriopoulos P, Oikonomopoulou A, Rigaki K, Kaplanis N, Rebelou D, Assimakopoulos G: An outbreak of Plasmodium vivax malaria in Lakonia, southern Greece, August-October 2009 [abstract]. Clin Microbiol Infect 2010, 16(Suppl 2):s396.

10. Bezirtzoglou C, Dekas K, Charvalos E: Climate changes, environment and infection: Facts, scenarios and growing awareness from the public health community within Europe. Anaerobe 2011, 17:337-340.

11. Florescu SA, Popescu CP, Calistru P, Ceausu E, Nica M, Toderan A, Zaharia M, Parola P: Plasmodium vivax malaria in a Romanian traveller returning from Greece, August 2011. Euro Surveill 2011, 16:pii $=19954$ [http://www.eurosurveillance.org/ViewArticle.aspx?Articleld=19954].

12. Santa-Olalla Peralta $P$, Vazquez-Torres MC, Latorre-Fandos E, Mairal-Claver $P$, Cortina-Solano P, Puy-Azon A, Adiego Sancho B, Leitmeyer K, LucientesCurdi J, Sierra-Moros MJ: First autochthonous malaria case due to Plasmodium vivax since eradication, Spain, October 2010. Euro Surveill 2010, 15: pii = 19684[http://www.eurosurveillance.orgNiewArticle.aspx? Articleld $=19684$.

13. Cuadros J, Calvente MJ, Benito A, Arévalo J, Calero MA, Segura J, Rubio JM: Plasmodium ovale malaria acquired in central Spain. Emerg Infect Dis 2002, 8:1506-1508.

14. Armengaud $A$, Legros $F$, Quatresous I, Barre $H$, Valayer $P$, Fanton $Y$, D'Ortenzio E, Schaffner F: A case of autochthonous Plasmodium vivax malaria, Corsica, August 2006. Euro Surveill 2006, 11:pii $=3081$ [http:/ $/ \mathrm{www}$. eurosurveillance.org/NiewArticle.aspx?Articleld=3081].

15. Doudier B, Bogreau H, DeVries A, Ponçon N, Stauffer WM, Fontenille D, Rogier C, Parola P: Possible autochthonous malaria from Marseille to Minneapolis. Emerg Infect Dis 2007, 13:1236-1238.

16. Baldari M, Tamburro A, Sabatinelli G, Romi R, Severini C, Cuccagna G, Fiorilli G, Allegri MP, Buriani C, Toti M: Malaria in Maremma, Italy. Lancet 1998, 351:1246-1247.

17. Sartori M, La Terra G, Pozzoli G, Franzini C: A case of autochthonous malaria in Italy. Scand J Infect Dis 1989, 21:357-358.

18. Kruger A, Rech A, Su XZ, Tannich E: Two cases of autochthonous Plasmodium falciparum malaria in Germany with evidence for local transmission by indigenous Anopheles plumbeus. Trop Med Int Health 2001, 6:983-985.

19. Hellenic Centers for Disease Control and Prevention (KEELPNO). [http:// www.keelpno.gr].

20. White NJ: The treatment of malaria. N Engl J Med 1996, 335:800-806.

doi:10.1186/1475-2875-11-52

Cite this article as: Loupa et al:: Autochthonous Plasmodium vivax malaria in a Greek schoolgirl of the Attica region. Malaria Journal 2012 11:52.

\section{Submit your next manuscript to BioMed Central and take full advantage of:}

- Convenient online submission

- Thorough peer review

- No space constraints or color figure charges

- Immediate publication on acceptance

- Inclusion in PubMed, CAS, Scopus and Google Scholar

- Research which is freely available for redistribution 